\title{
EVALUASI JENIS BAHAN PENSTABIL DAN KOAGULAN LATEKS PADA SISTEM REAKSI HIDROGENASI KATALITIK LATEKS KARET ALAM SKALA SEMI PILOT
}

\author{
Evaluation of Latex Stabilizer and Coagulant in the Catalytic Hydrogenation of \\ Natural Rubber Latex System at Semi Pilot Scale \\ Woro ANDRIANI ${ }^{1}$, Santi PUSPITASARI ${ }^{1 *}$, \\ Ahmad Nuruddin Zanki WIDIYANTORO ${ }^{2}$ dan MUSLICH $^{2}$ \\ ${ }^{1}$ Pusat Penelitian Karet \\ Jalan Salak Nomor 1 Bogor 16151 Jawa Barat \\ *Email : puspitasari.santi@puslitkaret.co.id \\ ${ }^{2}$ Departemen Teknologi Industri Pertanian, Institut Pertanian Bogor \\ Gedung Fateta Lantai 2, Kampus IPB Dramaga Bogor 16680 Jawa Barat
}

Diterima : 20 Mei 2018 / Disetujui : 28 Mei 2018

\begin{abstract}
Hydrogenated natural rubber produced from hydrogenation of natural rubber latex by using diimide compound is highly potential to be used to subtitute synthetic rubber EPDM type. One factor determine the succes of hydrogenation is the selection of latex stabilizer and coagulant. The aim of the research was to investigate the most ideal latex stabilizer and coagulant for hydrogenation of natural rubber latex at semi pilot scale at capacity as $2.5 \mathrm{Kg}$ latex concentrate/batch. Stabilizers were used consisted of strong base $\mathrm{NaOH}$ and anionic surfactant as Sodium Lauryl Sulfate (SLS), while the coagulant cover inorganic salt $\mathrm{CaCl}_{2}$ and organic acid as formic acid. The result showed that stabilizer type SLS and coagulant type formic acid were the most ideal additive to be used in diimide hydrogenation of natural rubber latex. The hydrogenated natural rubber obtained had high degree of hydrogenation (34 - 35\%), followed with low ash content (0.05-0.06\%).
\end{abstract}

Keywords: Coagulant; colloid stabilizer; hydrogenated natural rubber; natural rubber latex

\begin{abstract}
Abstrak
Karet alam terhidrogenasi yang dihasilkan dari reaksi hidrogenasi karet alam fasa lateks oleh senyawa diimida berpotensi digunakan sebagai pengganti
\end{abstract}

karet sintetik tipe EPDM. Salah satu faktor penentu keberhasilan pembuatan karet alam terhidrogenasi adalah pemilihan jenis bahan penstabil dan koagulan lateks. Penelitian ini bertujuan untuk mengetahui jenis bahan penstabil dan koagulan lateks yang paling ideal untuk digunakan dalam reaksi hidrogenasi lateks karet alam yang dijalankan pada skala semi pilot berkapasitas 2,5 Kg lateks pekat/batch. Bahan penstabil yang diujicobakan terdiri atas senyawa basa kuat $\mathrm{NaOH}$ dan surfaktan anionik Sodium Lauril Sulfat (SLS), sedangkan koagulan diambil dari jenis garam anorganik $\mathrm{CaCl}_{2}$ dan asam organik yaitu asam format. Hasil penelitian menunjukkan bahwa bahan penstabil jenis SLS dan koagulan jenis asam format merupakan bahan aditif terbaik yang dapat digunakan dalam reaksi hidrogenasi lateks karet dengan senyawa diimida. Karet alam terhidrogenasi yang dibuat dengan penambahan kedua bahan aditif tersebut memiliki nilai derajat hidrogenasi tertinggi (34 - 35\%), yang diikuti dengan kadar abu yang rendah $(0,05-0,06 \%)$.

Kata kunci : Karet alam terhidrogenasi; koagulan; lateks karet alam; penstabil koloid

\section{PENDAHULUAN}

Konsumsi karet sintetik dunia terus menunjukkan kecenderungan peningkatan, bahkan lebih tinggi daripada karet alam. 
Pada tahun 2015, konsumsi global karet sintetik mencapai 14,43 juta ton sedangkan karet alam hanya 12,35 juta ton (International Rubber Study Group [IRSG], 2016). Jenis karet sintetik yang paling banyak dibutuhkan oleh industri adalah karet sintetik untuk pembuatan ban kendaraan seperti SBR dan BR, karet sintetik tahan oksidasi termal seperti EPDM, IIR, CR, serta karet sintetik tahan minyak seperti NBR (Meyer, 2017). Melalui teknik modifikasi kimiawi, karet alam yang berasal dari species Hevea brasiliensis berpeluang digunakan untuk mensubstitusi berbagai jenis karet sintetik berbasis petroleum. Serta didukung dengan potensi ketersediaan karet alam yang sangat melimpah dan pemanfaatannya yang belum optimal terutama di negara produsen seperti Indonesia maka penggunaan karet alam sebagai calon bahan baku alternating green polymer dinilai cukup menjanjikan.

Hidrogenasi katalitik karet alam fasa lateks dengan mekanisme pemutusan ikatan rangkap tak jenuh $\mathrm{C}=\mathrm{C}$ menjadi ikatan tunggal jenuh $\mathrm{C}-\mathrm{C}$ dalam rantai molekul cis 1,4 poliisoprena oleh senyawa donor hidrogen dianggap sebagai prosedur yang paling sesuai untuk dapat meningkatkan ketahanan oksidasi dan sifat panas karet alam murni (Arayapranee \& Rempel, 2009). Karet alam mengandung sekitar 98\% ikatan tak jenuh yang mengakibatkannya mudah terdeteriorasi ketika terpapar oleh ozon, oksigen, dan sinar matahari (Kongparakul et al., 2011; Piyaareetham et al., 2013a). Karet alam terhidrogenasi memiliki struktur rantai lurus dengan kandungan ikatan tunggal jenuh yang dominan sehingga menyerupai karet sintetik tipe etilen-propilen diena monomer (EPDM) yang tahan terhadap proses oksidasi termal (Piya-areetham et al., 2013a; Piya-areetham et al., 2013b).

Keberhasilan reaksi hidrogenasi lateks karet alam sangat bergantung pada mutu lateks pekat sebagai bahan baku, jenis dan rasio komposisi pereaksi, jenis dan konsentrasi katalis dan bahan aditif, kondisi serta teknik reaksi (Mahittikul et al., 2007). Diimida yang diperoleh secara in-situ dari hasil oksidasi hidrasin hidrat oleh hidrogen peroksida merupakan senyawa donor hidrogen yang paling umum digunakan dalam hidrogenasi lateks karet alam (Smith et al., 2008; Cifriadi et al., 2017). Sementara penggunaan bahan aditif khususnya jenis penstabil lateks seperti senyawa basa kuat dan surfaktan difungsikan untuk menjamin kestabilan sistem koloid lateks karet alam sepanjang reaksi hidrogenasi berlangsung. Lateks karet alam yang tidak stabil dan mengalami koagulasi akan mengakibatkan senyawa diimida tidak dapat bereaksi dengan molekul karet yang terdispersi di dalam lateks, sehingga proses hidrogenasi menjadi tidak optimal.

Tahapan proses setelah reaksi hidrogenasi lateks karet alam turut menentukan karakteristik karet alam terhidrogenasi yang diperoleh. Sesuai dengan prosedur pengolahan karet alam konvensional, lateks karet alam terhidrogenasi akan digumpalkan dengan menambahkan koagulan sehingga terbentuk padatan karet alam terhidrogenasi. Syarat reaksi hidrogenasi lateks karet alam yang baik adalah tidak mengalami prakoagulasi ketika reaksi hidrogenasi sedang berlangsung, namun mudah digumpalkan ketika reaksi hidrogenasi telah selesai. Oleh karena itu, pemilihan jenis koagulan selain bahan penstabil lateks dianggap menjadi salah satu faktor penentu diperolehnya effisiensi produksi dan karakteristik karet alam terhidrogenasi yang tinggi.

Penelitian ini bertujuan untuk mengetahui jenis bahan penstabil serta bahan penggumpal (koagulan) lateks yang paling ideal digunakan dalam reaksi hidrogenasi pembentukkan karet alam terhidrogenasi yang dijalankan pada skala semi pilot berkapasitas 2,5 Kg lateks pekat/batch. Penentuan jenis bahan penstabil dan koagulan terbaik didasarkan pada pengamatan sepanjang reaksi hidrogenasi, proses koagulasi lateks karet alam terhidrogenasi dan hasil karakteristik kimiawi karet alam terhidrogenasi.

\section{BAHAN DAN METODE}

Penelitian telah dilaksanakan di Pabrik Percobaan dan Laboratorium Penguji Pusat Penelitian Karet. Bahan yang digunakan dalam penelitian ini digolongkan menjadi dua yaitu bahan pembuatan karet alam terhidrogenasi (HNR) dan reagent untuk analisis sifat kimia karet alam 
terhidrogenasi. Bahan yang diperlukan dalam sintesis HNR meliputi lateks pekat kadar amoniak tinggi (HANR) yang diperoleh dari PT. Trio Reka Krida Jakarta, hidrasin hidrat $\left(\mathrm{N}_{2} \mathrm{H}_{4}\right) \quad 35 \%$ didapatkan dari PT. Insoclay Acidatama Indonesia dan hidrogen peroksida $\left(\mathrm{H}_{2} \mathrm{O}_{2}\right) \quad 30 \%$ dari $\mathrm{CV}$. Brataco Chemika Bogor, bahan penstabil lateks berupa senyawa basa kuat $\mathrm{NaOH}$ dari CV. Setia Guna Bogor dan surfaktan anionik Sodium Lauril Sulfat (SLS) diperoleh dari PT. KAO Indonesia, katalis asam borat dari Merck, Na-thiosulfat $\left(\mathrm{Na}_{2} \mathrm{~S}_{2} \mathrm{O}_{3} \cdot{ }_{5} \mathrm{H}_{2} \mathrm{O}\right)$ sebagai bahan penetral sisa hidrogen peroksida yang tidak bereaksi, bahan penggumpal lateks berupa $\mathrm{CaCl}_{2}$ dan asam format juga diperoleh dari CV. Setia Guna Bogor. Sementara reagent untuk analisis yang seluruhnya pada grade pure analysis mencangkup Na-thiosulfat, kalium iodida, $\mathrm{K}_{2} \mathrm{Cr}_{2} \mathrm{O}_{7}, \mathrm{HCl}$, kanji, kloroform, larutan Wijs, terpentin, dan isooktan.

Peralatan yang digunakan meliputi reaktor tangki berpengaduk berkapasitas total $20 \mathrm{Kg}$ lateks pekat/batch yang dilengkapi dengan agitator mekanis serta seperangkat pengendali suhu, mesin creper untuk menggiling karet, oven, serta laboratory glassware. Instrument penggujian menggunakan FTIR Nicolet iS5 dari Thermo Scientific.

Penelitian ini dilakukan dalam tiga tahapan, yaitu karakterisasi bahan baku lateks pekat kadar amoniak tinggi (HANR), proses reaksi hidrogenasi lateks karet alam, dan karakterisasi sifat karet alam terhidrogenasi (HNR).

\section{Karakterisasi Bahan Baku Lateks Pekat Kadar Amoniak Tinggi}

Pengujian karakteristik lateks pekat kadar amoniak tinggi yang dilakukan berupa uji kadar karet kering (K3), kadar jumlah padatan (KJP), kadar amoniak atau alkalinitas, waktu kemantapan mekanik, dan FTIR. Kadar karet kering (K3) digunakan sebagai basis perhitungan jumlah pereaksi. Prosedur pengujian mengacu pada standar ASTM D 1076-06. Selain itu juga turut diuji sifat kimia karet alam murni dalam bentuk padat yang meliputi parameter bilangan iod, kadar gel, dan kadar abu sebagai pembanding.

\section{Reaksi Hidrogenasi Lateks Karet Alam}

Lateks pekat kadar amoniak tinggi dituangkan ke dalam reaktor, selanjutnya ke dalam lateks ditambahkan dengan variasi jenis dan konsentrasi bahan penstabil lateks serta 0,05 phr katalis asam borat. Variasi jenis bahan penstabil meliputi $\mathrm{NaOH}$ dan SLS pada konsentrasi masing-masing 1 dan 1,5 phr. Campuran lateks dengan bahan penstabil dan katalis terus diaduk pada kecepatan skala pengadukan $5 \mathrm{~Hz}$ dan suhu campuran ditingkatkan secara bertahap dari suhu ruang hingga tercapai suhu reaksi sebesar $40^{\circ} \mathrm{C}$. Ketika telah tercapai suhu reaksi, ke dalam campuran lateks ditambah dengan hidrasin hidrat 35\% pada dosis 42,5 phr dan hidrogen peroksida $30 \%$ pada dosis 35 phr sedikit demi sedikit (penambahan kedua reaktan dilakukan sepanjang waktu reaksi selama 6 jam). Setelah penambahan reaktan yang terakhir, waktu reaksi diperpanjang selama 30 menit. Proses selanjutnya ke dalam campuran lateks ditambahkan dengan 0,5 phr larutan $\mathrm{Na}-$ thiosulfat untuk menetralkan sisa hidrogen peroksida yang tidak bereaksi. Reaksi penetralan berlangsung selama 30 menit (sehingga total waktu reaksi hidrogenasi yang dilanjutkan dengan penetralan adalah selama 7 jam).

Lateks terhidrogenasi yang diperoleh diakhir reaksi kemudian dibagi menjadi 2 bagian dengan volume yang sama. Selanjutnya ke dalam masing-masing Iateks ditambahkan dengan larutan asam format $5 \%$ dan larutan $\mathrm{CaCl} 25 \%$ sehingga terbentuk gumpalan karet alam terhidrogenasi. Setiap gumpalan karet alam terhidrogenasi kemudian dicuci untuk menghilangkan impuritis yang tidak ikut tergumpalkan. Setiap gumpalan karet yang telah bersih kemudian digiling dengan mesin creper menjadi lembaran karet alam terhidrogenasi. Setiap lembaran karet alam terhidrogenasi basah yang diperoleh lalu dikering-anginkan selama 24 jam sebelum dikeringkan dalam oven pada suhu $100^{\circ} \mathrm{C}$ selama 3 jam. Lembaran karet terhidrogenasi kering lalu dikarakterisasi.

Evaluasi kinerja bahan penstabil dan bahan penggumpal (koagulan) lateks dilakukan secara kualitatif. Kinerja bahan penstabil koloid lateks dinilai optimal jika 
sepanjang berjalannya reaksi hidrogenasi tidak terjadi prakoagulasi atau tidak terbentuk koagulum karet terhidrogenasi. Sementara, kinerja bahan penggumpal dievaluasi kualitas serum yang terbentuk akibat proses koagulasi lateks karet alam terhidrogenasi setelah reaksi hidrogenasi selesai. Kode setiap sampel karet alam terhidrogenasi dirinci dalam Tabel 1 sebagai berikut.

\section{Karakterisasi Sifat Karet Alam Terhidrogenasi}

Karakterisasi sifat karet alam terhidrogenasi dilakukan untuk mengetahui tingkat keberhasilan proses reaksi hidrogenasi melalui parameter uji kualitatif dan kuantitatif. Uji kualitatif yang dilakukan adalah uji gugus fungsi dengan FTIR. Sementara uji kuantitatif meliputi bilangan iod dengan metode Wijs, derajat hidrogenasi, kadar gel dan kadar abu.

Tabel 1. Kode sampel karet alam terhidrogenasi

Table 1. Sample code of hydrogenated natural rubber

\begin{tabular}{|c|c|c|c|c|c|c|}
\hline $\begin{array}{l}\text { Kode } \\
\text { Code }\end{array}$ & $\begin{array}{c}\text { Lateks pekat } \\
\text { Latex } \\
\text { concentrate } \\
\text { (ml) }\end{array}$ & $\begin{array}{l}{\left[\mathrm{N}_{2} \mathrm{H}_{4}\right.} \\
35 \%] \\
(\mathrm{phr})\end{array}$ & $\begin{array}{l}{\left[\mathrm{H}_{2} \mathrm{O}_{2}\right.} \\
30 \%] \\
(\mathrm{phr})\end{array}$ & $\begin{array}{c}\text { Jenis } \\
\text { penstabil } \\
\text { Stabilizer }\end{array}$ & $\begin{array}{c}\text { Konsentrasi } \\
\text { penstabil } \\
\text { Stabilizer } \\
\text { concentration } \\
\text { (phr) }\end{array}$ & $\begin{array}{c}\text { Bahan penggumpal } \\
\text { Coagulant }\end{array}$ \\
\hline LPS 1 & 500 & & & Kontrol 1 & & $\mathrm{CaCl}_{2} 5 \%$ \\
\hline LPS 2 & 500 & & & Kontrol 2 & & As. Format 5\% \\
\hline $\mathrm{A} 1$ & 2500 & 42,5 & 35 & $\mathrm{NaOH} 10 \%$ & 1 & $\mathrm{CaCl}_{2} 5 \%$ \\
\hline $\mathrm{A} 2$ & 2500 & 42,5 & 35 & $\mathrm{NaOH} 10 \%$ & 1 & As. Format $5 \%$ \\
\hline B1 & 2500 & 42,5 & 35 & $\mathrm{NaOH} 10 \%$ & 1,5 & $\mathrm{CaCl}_{2} 5 \%$ \\
\hline B2 & 2500 & 42,5 & 35 & $\mathrm{NaOH} 10 \%$ & 1,5 & As. Format 5\% \\
\hline $\mathrm{C} 1$ & 2500 & 42,5 & 35 & SLS 5\% & 1 & $\mathrm{CaCl}_{2} 5 \%$ \\
\hline $\mathrm{C} 2$ & 2500 & 42,5 & 35 & SLS 5\% & 1 & As. Format $5 \%$ \\
\hline D1 & 2500 & 42,5 & 35 & SLS 5\% & 1,5 & $\mathrm{CaCl}_{2} 5 \%$ \\
\hline $\mathrm{D} 2$ & 2500 & 42,5 & 35 & SLS 5\% & 1,5 & As. Format 5\% \\
\hline
\end{tabular}

\section{HASIL DAN PEMBAHASAN}

\section{Karakterisasi Bahan Baku Lateks Pekat dan Karet Alam Murni}

Karakteristik lateks karet alam pekat penting untuk diketahui sebelum digunakan sebagai bahan baku dalam pembuatan karet alam terhidrogenasi. Melalui pengujian sifat lateks karet alam pekat maka dapat dinilai kelayakan lateks karet alam pekat tersebut ketika dikonversi menjadi karet alam terhidrogenasi. Tabel 2 merangkum hasil pengujian sifat lateks karet alam pekat. Secara umum, lateks karet alam pekat yang akan digunakan dalam pembuatan karet alam terhidrogenasi memiliki mutu sedikit lebih rendah daripada syarat standar mutu lateks pekat, kecuali pada parameter waktu kemantapan mekanik (WKM). WKM menggambarkan tingkat kestabilan lateks karet alam pekat akibat pengaruh pengadukan. Nilai WKM lateks karet alam pekat yang lebih tinggi dari persyaratan minimal berarti bahwa lateks karet alam pekat tersebut tetap stabil dalam fasa cair tanpa mengalami prakoagulasi meskipun dikenai efek pengadukan pada kecepatan tinggi. Dengan demikian meskipun memiliki nilai K3, KJP, dan kadar alkalinitas yang rendah, lateks karet alam pekat tetap dianggap layak digunakan sebagai bahan baku dalam pembuatan karet alam terhidrogenasi pada skala semi pilot.

Selisih nilai KJP dan K3 yang kurang dari $2 \%$ menunjukkan bahwa dalam lateks karet alam pekat tersebut hanya mengandung sedikit bahan non karet yang dapat bersifat sebagai impurities dalam reaksi hidrogenasi. Selanjutnya nilai kadar alkalinitas yang rendah diperkirakan disebabkan karena telah banyak kandungan ammoniak sebagai bahan pengawet lateks yang mengalami penguapan selama masa penyimpanan lateks karet alam pekat tersebut. Peran ammoniak sebagai penjamin kestabilan sistem koloid lateks akan digantikan oleh bahan penstabil (basa kuat dan surfaktan anionik) pada saat berlangsungnya reaksi hidrogenasi katalitik lateks karet alam pekat. 
Evaluasi Jenis Bahan Penstabil dan Koagulan Lateks pada Sistem

Reaksi Hidrogenasi Katalitik Lateks Karet Alam Skala Semi Pilot

Tabel 2. Sifat kimia lateks karet alam pekat

Table 2. Chemical properties of natural rubber latex concentrate

\begin{tabular}{clccc}
\hline No. & \multicolumn{1}{c}{$\begin{array}{c}\text { Parameter uji } \\
\text { Testing parameter }\end{array}$} & $\begin{array}{c}\text { Standar mutu } \\
\text { Quality standard }\end{array}$ & $\begin{array}{c}\text { Nilai } \\
\text { Value }\end{array}$ & $\begin{array}{c}\text { Satuan } \\
\text { Units }\end{array}$ \\
\hline 1 & Kadar Alkalinitas & Min 0,60 & 49,69 & $\% \mathrm{NH}_{3}$ \\
2 & Kadar Karet Kering & Min 59,8 & 59,16 & $\%$ \\
3 & Kadar Jumlah Padatan & Min 61,3 & 60,50 & $\%$ \\
4 & Waktu Kemantapan Mekanik & Min 650 & $>1800$ & detik \\
\hline
\end{tabular}

\section{Pengamatan Kestabilan dan Proses Koagulasi Lateks Karet Alam Terhidrogenasi}

Kestabilan sistem koloid lateks karet alam sepanjang berjalannya reaksi hidrogenasi menggunakan senyawa diimida yang dibangkitkan secara in-situ melalui oksidasi hidrasin hidrat oleh hidrogen peroksida dengan penambahan bahan penstabil jenis basa kuat $\mathrm{NaOH}$ maupun surfaktan anionik SLS pada dosis 1 phr dan 1,5 phr terlihat cukup baik. Kestabilan sistem koloid lateks karet alam terhidrogenasi tersebut diindikasikan dengan tidak terbentuknya koagulum lateks karet alam terhidrogenasi. Pembentukan koagulum lateks melalui proses prakoagulasi menjadi ciri ketidak-stabilan sistem koloid lateks karet alam. Reaksi hidrogenasi pada lateks karet alam sangat rentan dengan terjadinya ketidak-stabilan sistem koloid lateks karena mekanisme reaksi hidrogenasi yang berjalan secara eksotermis menyebabkan peningkatan suhu reaksi. Panas reaksi selanjutnya akan mengakibatkan kerusakan lapisan molekul air disekeliling partikel karet yang berfungsi sebagai pelindung partikel karet alam tersebut. Dengan penambahan bahan penstabil maka akan menggantikan fungsi lapisan molekul air yang dapat melindungi partikel karet dari proses penggumpalan atau ketidak-stabilan.

Syarat proses hidrogenasi lateks karet alam yang baik adalah bahwa lateks karet alam tidak mengalami prakoagulasi ketika masih direaksikan dengan senyawa diimida, namum akan mudah digumpalkan dengan penambahan bahan penggumpal (koagulan) ketika reaksi hidrogenasi telah dihentikan. Penggumpalan lateks merupakan mekanisme perubahan fasa sol menjadi gel melalui penurunan muatan listrik akibat penurunan $\mathrm{pH}$ lateks (penambahan asam $\mathrm{H}^{+}$) serta penambahan elektrolit yang mengandung kation (misalnya $\mathrm{Ca}^{2+}$ ) sehingga menyebabkan penurunan potensial elektrokinetik (Gabungan Perusahaan Karet Indonesia [GAPKINDO], 2009).

Pada penelitian ini terlihat bahwa $\mathrm{CaCl}_{2}$ maupun asam format dapat berfungsi dengan baik sebagai bahan penggumpal lateks karet alam terhidrogenasi berbahan penstabil basa kuat $\mathrm{NaOH}$ yang ditandai dengan terbentuknya koagulum lateks bertekstur kenyal dan berwujud gumpalan padatan putih. Sedangkan pada lateks karet alam terhidrogenasi berbahan penstabil SLS, baik $\mathrm{CaCl}_{2}$ maupun asam format menghasilkan koagulum lateks karet alam terhidrogenasi yang berwujud menyerupai granul. Bahkan pada penggumpalan dengan $\mathrm{CaCl}_{2}$ menghasilkan warna serum yang keruh yang berarti bahwa penggumpalan tidak berjalan sempurna, masih banyak partikel karet alam terhidrogenasi yang belum tergumpalkan oleh $\mathrm{CaCl}_{2}$.

Jumlah asam format yang digunakan untuk menggumpalkan lateks karet alam terhidrogenasi lebih banyak dibandingkan jumlah $\mathrm{CaCl}_{2}$. Hal ini dikarenakan selain untuk menggumpalkan lateks, asam format juga digunakan untuk menetralkan kandungan amoniak dalam lateks karet alam pekat kadar ammoniak tinggi yang merupakan bahan baku dalam pembuatan lateks karet alam terhidrogenasi. Namun demikian, untuk mengetahui efektivitas pemilihan bahan penstabil dan bahan penggumpal lateks pada proses hidrogenasi lateks karet alam tetap didukung dengan data hasil analisis kuantitatif sifat kimiawi karet alam terhidrogenasi. 

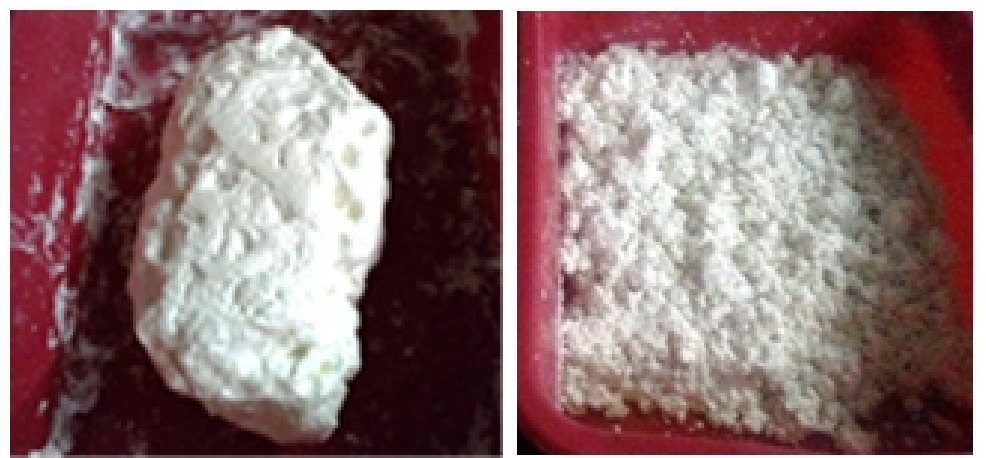

Gambar 1. Koagulum karet alam terhidrogenasi berpenstabil NaOH (kiri) dan SLS (kanan) Figure 1. Hydrogenated natural rubber coagulum, stabilized with $\mathrm{NaOH}$ (left) and SLS (right)

\section{Karakterisasi Kimiawi Karet Alam Terhidrogenasi}

Pembentukan karet alam terhidrogenasi secara hidrogenasi katalitik lateks karet alam oleh senyawa diimida pada skala semi pilot dikonfirmasi melalui analisis kualitatif menggunakan spektrofotometer FTIR. Gambar 2 menyajikan spektra FTIR karet alam murni yang digumpalkan dengan $\mathrm{CaCl}_{2}$ (LPS1) dan asam format (LPS2) dibandingkan dengan karet alam terhidrogenasi yang digumpalkan dengan $\mathrm{CaCl}_{2}$ (A1) dan asam format (A2). Sedangkan intepretasi data FTIR tersebut dirinci dalam Tabel 3.

Berdasarkan Gambar 2 terlihat bahwa spektra karet alam murni (LPS1 dan LPS2) menunjukkan pola yang identik dengan spektrum karet alam terhidrogenasi (A1 dan A2). Spektra FTIR karet alam murni dicirikan dengan munculnya pita serapan tajam pada puncak bilangan gelombang $1663 \mathrm{~cm}^{-1}$ untuk ikatan rangkap tak jenuh $\mathrm{C}=\mathrm{C}$ vibrasi ulur dan $833 \mathrm{~cm}^{-1}$ untuk ikatan $=\mathrm{C}-\mathrm{H}$ vibrasi tekuk (Ibrahim et al., 2014; Azhar et al., 2017). Pita serapan penting lain yang turut mengidentifikasi karet alam antara lain terlihat pada bilangan gelombang $2959 \mathrm{~cm}^{-1}$ (ikatan $\mathrm{CH}_{3}$, vibrasi ulur), 1447 $\mathrm{cm}^{-1}$ (ikatan $\mathrm{CH}_{3}$, vibrasi tekuk), $2852 \mathrm{~cm}^{-1}$ (ikatan $\mathrm{CH}_{2}$, vibrasi ulur), $1375 \mathrm{~cm}^{-1}$ (ikatan $\mathrm{CH}_{2}$, vibrasi tekuk) serta $739 \mathrm{~cm}^{-1}$ (ikatan $\left.-\left(\mathrm{CH}_{2}\right)_{3}\right)$ (Mahittikul et al., 2007; Mahittikul et al., 2009; Arayapranee \& Rempel, 2013). Sementara pada spektra FTIR karet alam terhidrogenasi terlihat bahwa terjadi penurunan intensitas puncak serapan (\% transmittance) terutama pada bilangan gelombang $833 \mathrm{~cm}^{-1}$ yang diikuti dengan peningkatan intensitas puncak serapan $(\%$ transmittance) pada bilangan gelombang 739 $\mathrm{cm}^{-1}$. Perubahan intensitas puncak serapan pada kedua bilangan gelombang tersebut mengkonfirmasi terjadinya pemutusan ikatan rangkap $=\mathrm{CH}$ menjadi $-\mathrm{CH}_{2}$ oleh senyawa diimida pada rantai molekul karet alam, cis 1-4 poliisoprena. Khusus pada spektra FTIR karet alam terhidrogenasi A1 terlihat adanya puncak serapan pada bilangan gelombang $3314 \mathrm{~cm}^{-1}$ yang berarti bahwa pada karet alam terhidrogenasi tersebut mengalami reaksi samping depolimerisasi. Depolimerisasi akan memutus rantai panjang molekul karet alam menjadi rantai molekul yang lebih pendek.

Secara kuantitatif konversi karet alam murni menjadi karet alam terhidrogenasi diketahui dari nilai derajat hidrogenasi yang dihitung berdasarkan nilai bilangan iod (Gambar 3). Derajat hidrogenasi merupakan perbandingan nilai bilangan iod karet alam terhidrogenasi terhadap karet alam murni. Bilangan iod seringkali digunakan untuk menganalisis tingkat ketidak-jenuhan suatu senyawa. Karet alam murni yang memiliki tingkat ketidakjenuhan tinggi akan memiliki bilangan iod yang lebih tinggi daripada karet alam terhidrogenasi. Berdasarkan Gambar 3 terlihat bahwa nilai derajat hidrogenasi karet alam terhidrogenasi yang disintesis dengan penambahan basa kuat $\mathrm{NaOH}$ cenderung lebih rendah daripada dengan penambahan surfaktan anionik SLS sebagai bahan penstabil. Surfaktan anionik memiliki muatan ion negatif yang sama dengan karet alam sehingga dapat berfungsi optimal sebagai bahan penstabil koloid lateks selama reaksi hidrogenasi. Surfaktan anionik terutama golongan sulphonic acid salt seperti SLS dapat dengan cepat terserap pada partikel karet (Singh \& Mei, 2013). 

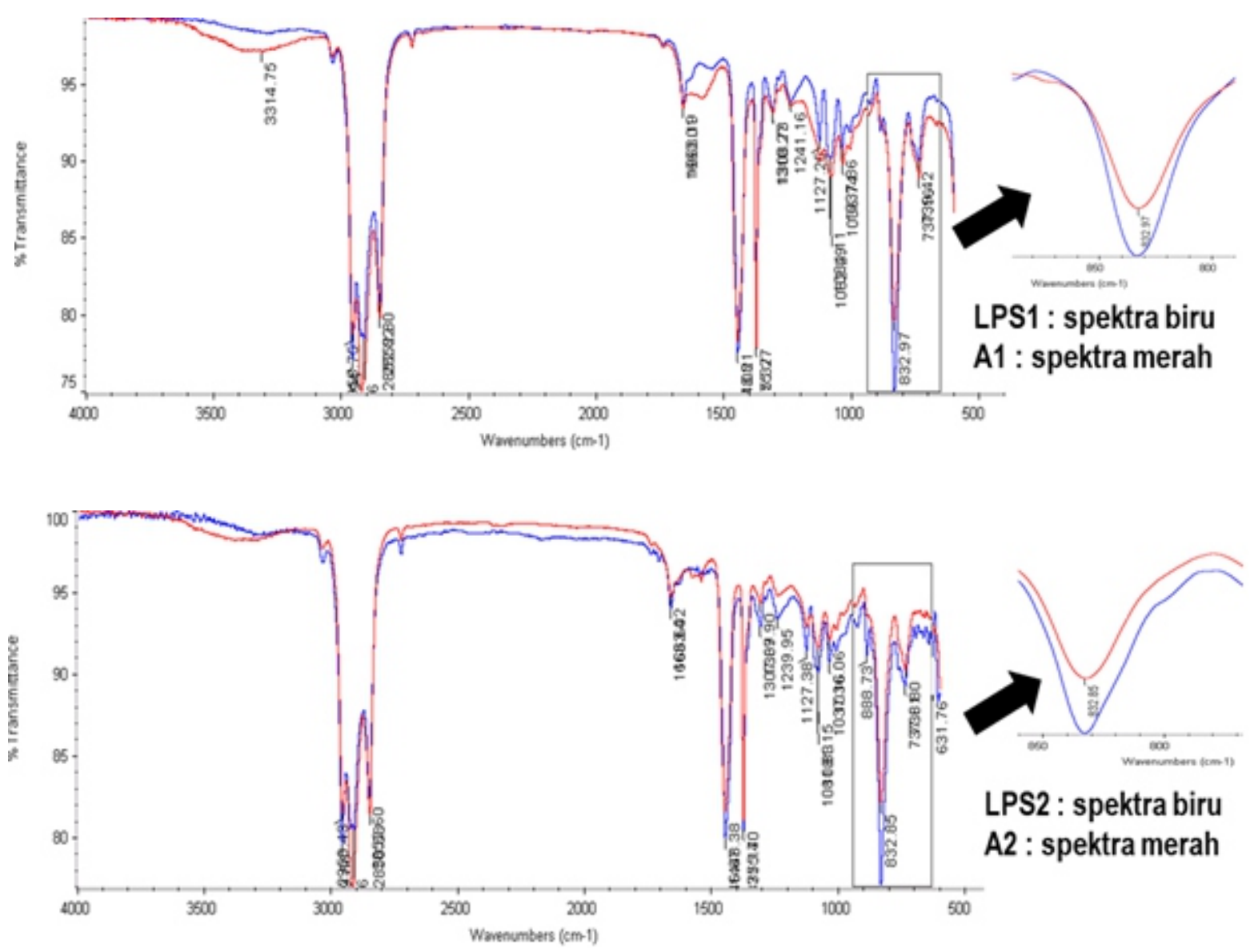

Gambar 2. Spektra FTIR karet alam murni (LPS 1 dan LPS2) dan karet alam terhidrogenasi (A1 dan A2)

Figure 2. FTIR spectrum of pure natural rubber (LPS1 and LPS2) and hydrogenated natural rubber (A1 and A2)

Tabel 3. Intepretasi data spektra FTIR

Table 3. Intepretation data of FTIR spectrum

\begin{tabular}{|c|c|c|c|c|}
\hline \multicolumn{4}{|c|}{$\begin{array}{c}\text { Bilangan gelombang spektra FTIR } \\
\text { Wavenumber on FTIR spectrum }\end{array}$} & \multirow{2}{*}{$\begin{array}{l}\text { Vibrasi dan gugus fungsi } \\
\text { Vibration and functional group }\end{array}$} \\
\hline $\begin{array}{l}\text { LPS1 } \\
\end{array}$ & $\overline{\text { LPS2 }}$ & A1 & A2 & \\
\hline & & 3314,75 & & Ulur-OH dalam asam karboksilat \\
\hline 2959,94 & 2959,86 & 2958,75 & 2958,43 & Ulur -C- $\mathrm{H}_{3}$ Asimeteri \\
\hline 2914,06 & 2914,06 & 2923,86 & 2918,08 & Ulur $-\mathrm{C}-\mathrm{H}_{2}-$ Asimeteri \\
\hline 2852,80 & 2852,60 & 2852,82 & 2850,88 & Ulur $-\mathrm{C}-\mathrm{H}_{2}-$ Simeteri \\
\hline 1663,19 & 1663,64 & 1663,01 & 1663,02 & Ulur $\mathrm{C}=\mathrm{C}$ \\
\hline 1447,08 & 1446,67 & 1448,21 & 1448,38 & Tekuk $-\mathrm{C}-\mathrm{H}_{3}$ Asimeteri \\
\hline 1375,27 & 1375,17 & 1375,37 & 1375,40 & Tekuk -C- $\mathrm{H}_{2}$ Simeteri \\
\hline 1037,86 & 1037,16 & 1036,74 & 1036,06 & Ulur atau wagging $\mathrm{CH}_{3} \mathrm{C}=\mathrm{C}$ \\
\hline 833,69 & 833,23 & 832,97 & 832,85 & Tekuk $-\mathrm{C}-\mathrm{H}=\mathrm{C}-\mathrm{H}$ \\
\hline 739,42 & 737,81 & 737,16 & 736,80 & Ikatan $-\left(\mathrm{CH}_{2}\right)_{n}^{-}$ \\
\hline
\end{tabular}




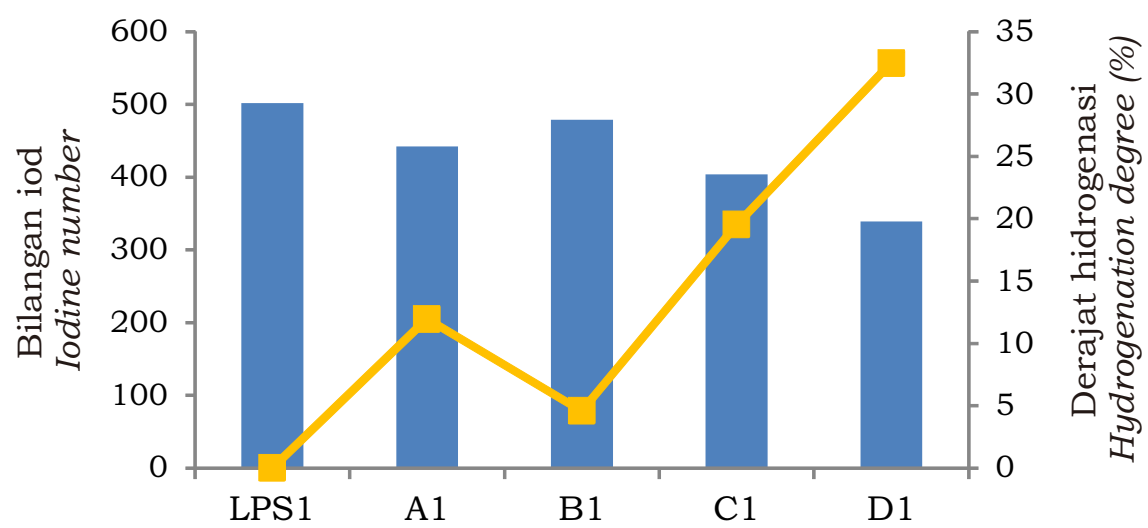

Sampel karet alam dengan koagulan $\mathrm{CaCl}_{2}$ Natural rubber sample with $\mathrm{CaCl}_{2}$ coaguant

Bilangan Iod - -Derajat Hidrogenasi

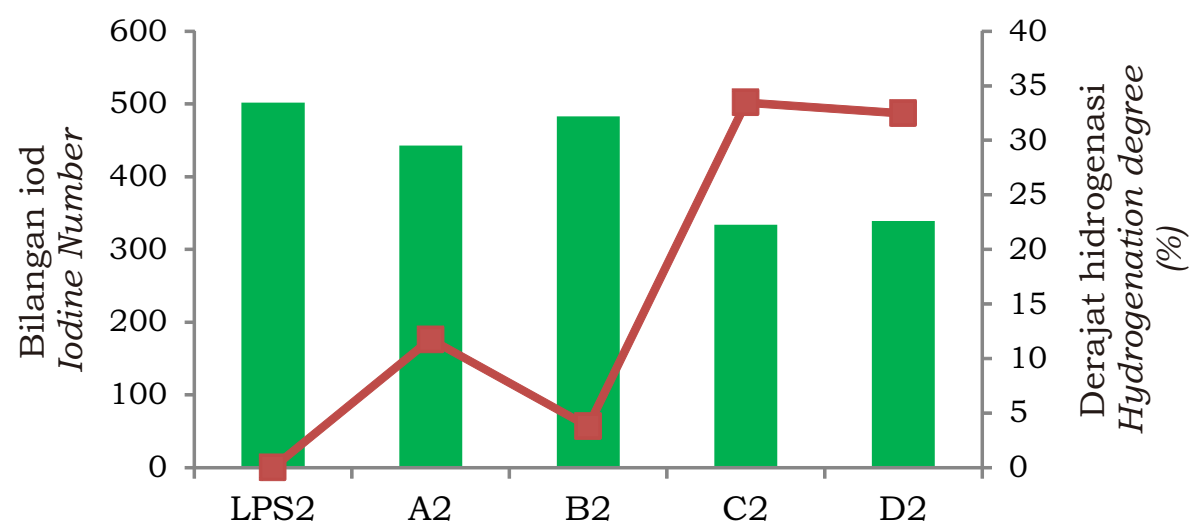

Sampel karet alam dengan koagulan asam format Natural rubber sample with formic acid coagulant

\section{Bilangan Iod $\rightarrow-$ Derajat Hidrogenasi}

Gambar 3. Bilangan iod dan derajat hidrogenasi karet alam terhidrogenasi

Figure 3. Iod number and degree of hydrogenation of hydrogenated natural rubber

Faktor lain yang turut mempengaruhi kinerja bahan penstabil terhadap berlangsungnya reaksi hidrogenasi lateks karet alam adalah pengaruh bahan penstabil tersebut terhadap $\mathrm{pH}$ reaksi. Lin et al (2003) menyatakan bahwa pada suhu reaksi yang ditetapkan sama maka laju reaksi hidrogenasi secara signifikan dipengaruhi oleh $\mathrm{pH}$. Pada $\mathrm{pH}<8$ reaksi berjalan lambat, saat $\mathrm{pH}>8$ laju reaksi naik dengan cepat, dan pada $\mathrm{pH}=10$ laju reaksi hidrogenasi mencapai maksimum. Surfaktan SLS menyebabkan campuran reaktan memiliki $\mathrm{pH}=10$ sehingga menghasilkan laju reaksi hidrogenasi yang maksimum. Sedangkan, penambahan $\mathrm{NaOH}$ justru menaikkan $\mathrm{pH}$ reaktan hingga di atas 10 yang akibatnya menghambat reaksi hidrogenasi lateks karet alam oleh senyawa diimida. Sementara pemilihan jenis koagulan baik $\mathrm{CaCl}_{2}$ maupun asam format memberikan nilai bilangan iod karet alam terhidrogenasi yang sebanding. Pemilihan koagulan tidak berdampak terhadap nilai bilangan iod dikarenakan koagulan ditambahkan ke dalam lateks karet alam ketika reaksi hidrogenasi telah selesai.

Parameter kadar gel dan kadar abu juga digunakan sebagai dasar penilaian 
mutu karet alam terhidrogenasi. Hasil pengukuran kadar gel dan kadar abu secara berurutan ditampilkan dalam Gambar 4 dan Gambar 5. Dari Gambar 4 terlihat bahwa karet alam terhidrogenasi memiliki kadar gel yang lebih tinggi daripada karet alam murni, sesuai hasil penelitian Ji et al (2017) yang menunjukkan bahwa dengan peningkatan derajat hidrogenasi maka diikuti dengan peningkatan kadar gel karet alam terhidrogenasi. Keberadaan hidrogen peroksida dalam sistem reaksi hidrogenasi lateks karet alam turut menyebabkan terjadinya pembentukan ikatan silang antar bahan non karet yang mengakibatkan naiknya kadar gel dalam karet alam terhidrogenasi dibandingkan pada karet alam murni (Veni \& Ma'zam, 2010). Bahan penstabil basa kuat $\mathrm{NaOH}$, cenderung menghasilkan kadar gel karet alam terhidrogenasi yang rendah daripada bahan penstabil surfaktan anionik SLS. Penambahan $\mathrm{NaOH}$ dalam reaksi hidrogenasi lateks karet alam memicu terjadinya reaksi samping yaitu hidrolisis bahan non karet berupa protein dan lemak. Mekanisme reaksi hidrolisis ini tidak terjadi pada sistem reaksi hidrogenasi lateks karet alam dengan penambahan bahan penstabil surfaktan anionik SLS. Sehingga seluruh bahan non karet akan mengalami reaksi ikatan silang yang mengakibatkan tingginya nilai kadar gel pada karet alam terhidrogenasi berpenstabil surfaktan anionik SLS.
Penggunaan koagulan garam anorganik jenis $\mathrm{CaCl}_{2}$ mengakibatkan karet alam terhidrogenasi mengandung kadar abu yang tinggi. Temuan ini sesuai dengan hasil penelitian Pimrat dan Poolsawat (2017) yang menyatakan bahwa penggunaan $\mathrm{CaCl}_{2}$ mengakibatkan karet STR 20 memiliki kadar zat menguap dan kadar abu yang tinggi bahkan melebihi standar mutu karet STR 20. Hal ini dikarenakan dalam garam anorganik $\mathrm{CaCl}_{2}$ terdapat senyawa sumber abu yang cukup besar yaitu kalsium (Ca) dan sifatnya yang hidroskopis sehingga mudah menyerap air. Kandungan abu akan berpengaruh terhadap sifat mekanik vulkanisat karet. Karet dengan kandungan abu yang tinggi akan memiliki sifat mekanik yang rendah ketika digunakan sebagai bahan baku dalam pembuatan barang jadi karet. Selain itu, menurut Li et al (2010) koagulan $\mathrm{CaCl}_{2}$ akan mengakibatkan karet memiliki sifat kestabilan panas yang rendah.

Oleh karena itu hingga saat ini, asam format dinilai sebagai koagulan terbaik untuk karet alam murni maupun karet alam terhidrogenasi. Mekanisme penggumpalan lateks karet alam oleh asam format dilakukan melalui netralisasi muatan negatif lapisan protein-lemak yang menyelubungi partikel karet oleh muatan positif yang berasal dari ion $\mathrm{H}^{+}$dari senyawa asam format sehingga tidak merusak mutu partikel karet (Baimark et al., 2008). Selain itu dalam asam format juga tidak mengandung senyawa sumber abu dan tidak bersifat hidroskopis.

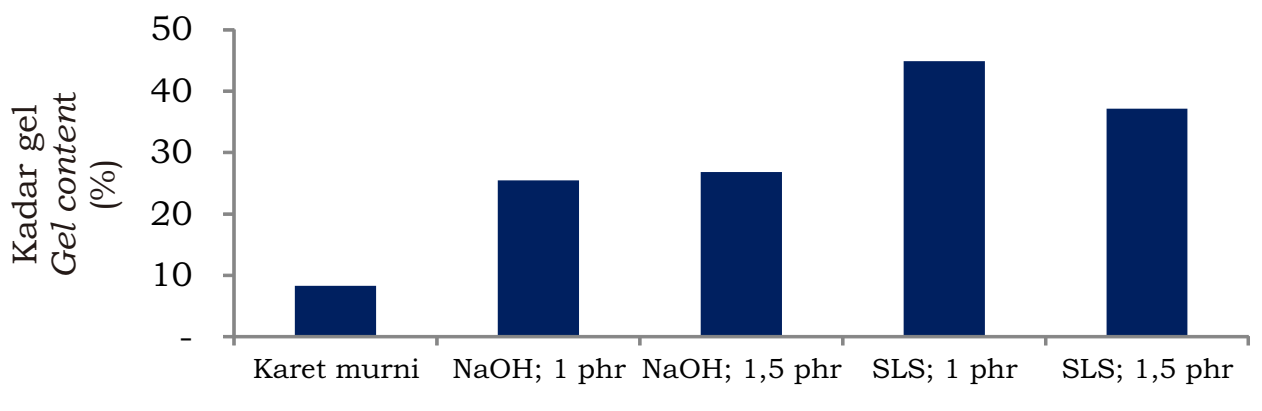

Sampel karet

Rubber sample

Gambar 4. Kadar gel karet alam terhidrogenasi

Figure 4. Gel content of hydrogenated natural rubber 


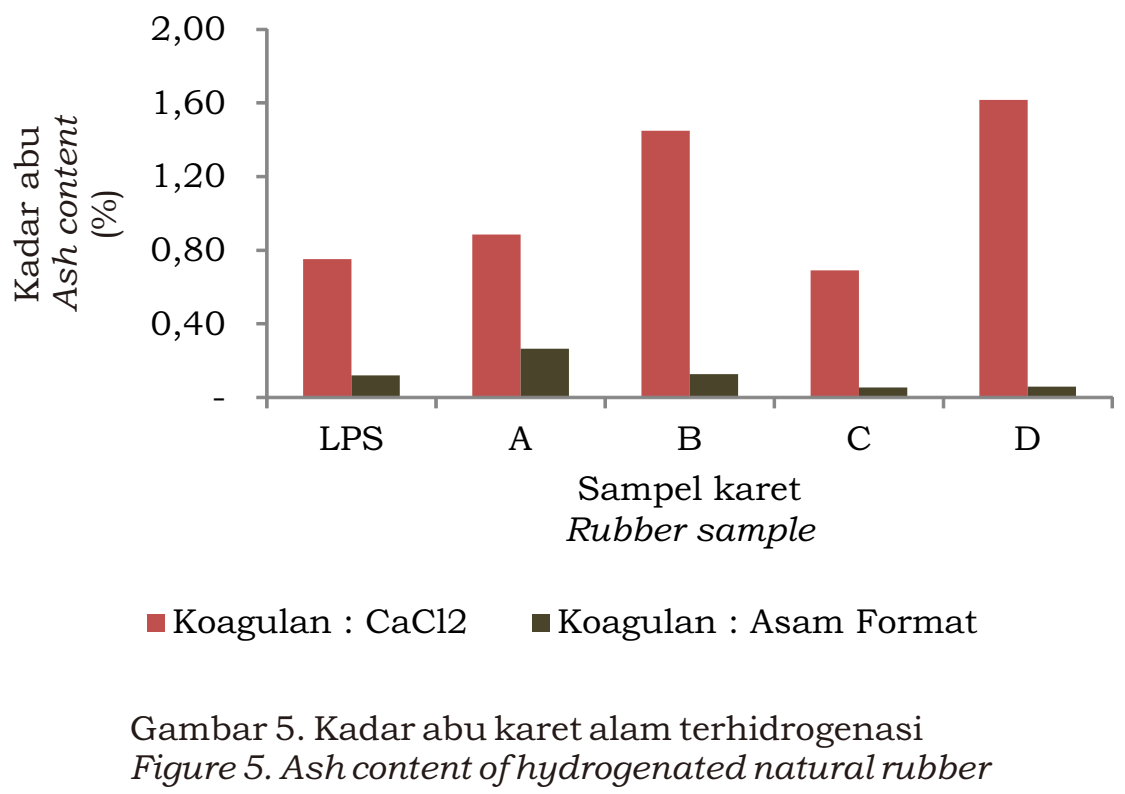

\section{KESIMPULAN}

Mengacu pada penelitian yang telah dilaksanakan maka dapat ditarik kesimpulan bahwa bahan penstabil jenis surfaktan anionik SLS dan koagulan jenis asam organik yaitu asam format merupakan bahan aditif terbaik yang dapat digunakan dalam reaksi hidrogenasi lateks dengan senyawa diimida pada pembentukan karet alam terhidrogenasi yang dijalankan pada skala semi pilot berkapasitas 2,5 Kg lateks pekat/batch. Karet alam terhidrogenasi yang dibuat dengan penambahan kedua bahan aditif tersebut memiliki nilai derajat hidrogenasi tertinggi ( $34-35 \%)$, yang diikuti dengan kadar abu yang rendah $(0,05$ $0,06 \%)$. Surfaktan anionik memiliki muatan ion yang sama dengan lateks karet alam sehingga dapat berfungsi dengan baik dalam menjaga kestabilan sistem koloid lateks saat berlangsungnya reaksi hidrogenasi. Sementara, asam format lebih sesuai digunakan sebagai koagulan lateks karet alam terhidrogenasi dibandingkan dengan $\mathrm{CaCl}_{2}$. Asam format tidak merusak mutu karet alam terhidrogenasi yang ditunjukkan dengan nilai kadar abu yang tetap rendah.

\section{UCAPAN TERIMA KASIH}

Terima kasih dan penghargaan tinggi penulis sampaikan kepada Direktorat Jenderal Penguatan Riset dan Pengembangan Kementerian Riset, Teknologi dan Pendidikan Tinggi atas bantuan pendanaan riset yang telah diberikan kepada Pusat Penelitian Karet melalui Program Insentif Sistem Inovasi Nasional (INSINas) Gelombang 1 TA 2018 sesuai dengan Kontrak Pelaksanaan Insentif Penelitian Nomor : 21/INS-1/PPK/E4/2018.

\section{DAFTAR PUSTAKA}

Arayapranee, W., \& Rempel, G.L. (2009). Synthesis and mechanical properties of diimide hydrogenated natural rubber vulcanizates. Journal of Applied Polymer Science, 114(6), 4066 - 4075. Doi : 10.1002/app.31132.

Arayapranee, W., \& Rempel, G.L. (2013). Effects of polarity on the filler-rubber interaction and properties of silica filled grafted natural rubber composite. Journal of Polymers, 2013, 1-9. Doi : $10.1155 / 2013 / 279529$. 
Azhar, N.H.A., Rasid, H.Md., \& Yusoff, S.F.M. (2017). Epoxidation and hydrocylation of liquid natural rubber. Sains Malaysiana, 46(3), 485-491. Doi : 10. 17576/jsm-2017-4603-17.

Baimark, Y., Threeporn, J., Dumrongchai, N., Srisuwan, Y., \& Kotsaeng, N. (2008). Utilization of wood vinegars as sustainable coagulating and antifungal agents in the production of natural rubber sheets. Journal of Enviromental Science and Technology, 1(4), 157-163.

Cifiradi, A., Chalid, M., \& Puspitasari, S. (2017). Characterization of hydrogenated natural rubber synthesized by diimide transfer hydrogenation. International Journal of Technology, 8(3), 448-457. Doi : 10. 14716/ijtech.v8i3.1991.

Gabungan Perusahaan Karet Indonesia. (2009). Pengetahuan lateks. Jakarta, Indonesia: GAPKINDO

Ibrahim, S., Daik, R., \& Abdullah, I. (2014). Functionalization of liquid natural rubber via oxidative degradation of natural rubber. Polymers, 6, 29282941. Doi : $10.3390 /$ polym6122928

International Rubber Study Group. (2016). Rubber Bulletin Statistic. Singapore, Singapore: IRSG.

Ji, M., Yue, D., Wu, X., \& Zhang, L. (2017). Structure and performance of hydrogenated natural rubber prepared by the latex method. Plastics Rubber and Composites, 46(6), 1-6. Doi : 10. 1080/14658011.2017.1318500.

Kongparakul, S., Ng, F.T.T., \& Rempel, G.L. (2011). Metathesis hydrogenation of natural rubber latex. Applied Catalysis A: General, 405(1-2), 129 - 136. Doi : $10.1016 /$ j.apcata.2011.07.039

Li, C.P., Zhong, J.P., Yang, L., Li, S.D., Kong, L.X., \& Hou, T.T. (2010). Studies on the properties and the thermal decomposition kinetics of natural rubber prepared with calcium chloride. e-Polymers, 2010(72), 1-9.
Lin, X., Pan, Q., \& Rempel, G.L. (2003). Cupric ion catalyzed diimide production from the reaction between hydrazine and hydrogen peroxide. Journal of Applied Catalysis A General, 263, 27-32. Doi : 10.1016/j.apcata. 2003.11.035.

Mahittikul, A., Prasassarakich, P., \& Rempel, G.L. (2007). Diimide hydrogenation of natural rubber latex. Journal of Applied Polymer Science, 105(3), 1188 - 1199. Doi : 10.1002/app.25944

Mahittikul, A., Prasassarakich, P., \& Rempel, G.L. (2009). Hydrogenation of natural rubber latex in the presence of $\left[\operatorname{Ir}(\operatorname{cod})\left(\mathrm{Pcy}_{3}\right)(\mathrm{py})\right] \mathrm{PF}_{6}$. Journal of Molecular Catalysis A: Chemical, 297, 135-141. Doi : 10.1016/j.molcata. 2008.09.006.

Meyer, B. (2017). Optimistic SR projections lead to saturated market. Rubber and Plastic News. Diakses dari www.rubber news.com

Pimrat, P., \& Poolsawat, W. (2017). Influence of coagulants to the production of cup lump and standard thai rubber (STR20) on the properties of rubber. Proceedings of the International Rubber Conference 2017 (p. 639). Jakarta, Indonesia: IRRI - IRRDB.

${ }^{a}$ Piya-areetham, P., Prasassarakich, P., \& Rempel, G.L. (2013). Organic solventfree hydrogenation of natural rubber latex and synthetic polyisoprene emulsion catalyzed by water-soluble rhodium complexes. Journal of Molecular Catalysis A: Chemical, 372, 151 - 159. Doi : 10.1016/j.molcata. 2013.02.025

${ }^{\mathrm{b}}$ Piya-areetham, P., Prasassarakich, P., \& Rempel, G.L. (2013). Aqueous-phase hydrogenation of nanosized polyisoprene emulsion using rhodium catalysts. European Polymer Journal, 49(9), 2584 - 2595. Doi : 10. 1016/j.eurpolymj.2013.05.025

Singh, M., \& Mei, E.L.H. (2013). Surfactant and their use in latex technology. $M R B$ Rubber Technology Development, 13(2), 33-36. 
Smit, C., Fraaije, M.W., \& Minnaard, A.J. (2008). Reduction of carbon-carbon double bond using organocatalytically generated diimide. Journal of Organic Chemistry, 73(23), 9482 - 9485. Doi : $10.1021 /$ jo801588d
Veni, B.N.K., \& Ma'zam, M.S. (2010). Hydrogenated natural rubber from different types of preserved latex. Journal of Rubber Research, 13(2), 103-109. 